\title{
Сравнительный анализ популяций Corydalis bracteata (Steph. ex Willd.) Pers. s. l., произрастающих в горах Южной Сибири
}

\section{Comparative analysis of populations Corydalis bracteata (Steph. ex Willd.) Pers. s. l., growing in the mountains of Southern Siberia}

\author{
Рябова К. К., Ямских И.Е. \\ Ryabova. K. K., Yamskih I.E. \\ Сибирский федеральный университет, г. Красноярск, Россия.E-mail: ryabova.kseniya.k@mail.ru, iyamskikh@mail.ru
}

Siberian Federal University, Krasnoyarsk, Russia

Peфepam. Проведен сравнительный морфолого-генетический анализ популяций Corydalis bracteata (Steph. ex Willd.) Pers. s. 1., произрастающих в Красноярской лесостепи, Восточном, Западном Саянах, Кузнецком Алатау. Выявлено, что изученные популяции характеризуются морфологическим и генетическим разнообразием. Диагностическими признаками, позволяющими разделить популяции хохлатки, являются наличие и форма клубенька, форма и степень рассеченности прицветника.

Ключевые слова. Кластерный анализ, Красноярский край, морфолого-генетический анализ популяций, хохлатка крупноприцветниковая, ISSR-PCR.

Summary. Comparative morphology-genetic analysis of Corydalis bracteata (Steph. Ex Willd.) Pers. s. 1. populations from Krasnoyarsk forest-steppe, Kuznetskiy Alatau, East and West Sayan Mountains have been made. It was revealed that there is a morphological and genetic diversity between populations. Presence and shape of additional tuber together with shape and dissection of flower bract are the diagnostic features for differentiation of populations.

Key words. Cluster analysis, Corydalis bracteata s.1., ISSR-PCR, Krasnoyarsk region, morphological and genetic population analysis.

Одной из наиболее интересных и относительно слабо изученных в Южной Сибири является группа весенних эфемероидов, принадлежащих к роду Corydalis Vent. Объектом нашего исследования является желтоцветковая хохлатка (Corydalis bracteata s.l.). Большинство исследователей считают, что на территории южной части Красноярского края и Хакасии встречается одни вид желтоцветковой хохлатки с клубневидным корнем - Corydalis bracteata (Положий и др.,1975; Михайлова, 1982; Пешкова, 1994). Н. В. Степанов выделяет три вида - C. bracteata, C. bombylina Stepanov и C. talpina Stepanov (Степанов, 2015). В связи с этим возникла необходимость пересмотра объема рода и выявления таксономически значимых признаков.

Цель работы: провести сравнительный морфолого-генетический анализ популяций Corydalis bracteata s.l., произрастающих в сообществах Южной Сибири.

При анализе популяций определяли возрастной состав, плотность побегов, оценивали изменчивость вегетативных и генеративных признаков, изучали генетическую вариабельность на основе данных ISSR-PCR анализа. Статистическая обработка морфологических и генетических данных произведена в программах Statistica 7.0, Popgene version 1.32 и TFPGA version 1.3.

Сбор материала проводился в период с 2015 по 2018 гг. Объектом исследований явились популяции $C$. bracteata, произрастающие в следующих местообитаниях. Красноярская лесостепь (Емельяновский район): Cb-1 - березово-еловый лес разнотравно-осочковый (окр. п. Щебзавод), $\mathrm{Cb}-2$ сосново-березовый лес разнотравный (окр. с. Арейское), Cb-3 - смешанный осочково-разнотравный лес (окр. д. Крутая). Восточный Саян (Березовский район): Cb-4 - осиново-березовый лес высокотравный (пойма руч. Лалетина), Cb-5 - пихтарник разнотравно-папоротниковый (дол. р. Бирюса). Западный 
Саян (Ермаковский район): Cb-6 - пойменный ивняк высокотравный (долина р. Б. Кебеж), Cb-7 - ивняк папоротниково-широкотравный (пойма Алеева ключа), Cb-8 - пихтарник крупнотравно-широкотравный (пойма p. Чебижек), Cb-9 - субальпийское пихтовое редколесье (смотровая площадка природного парка «Ергаки»), Cb-10 - субальпийский луг высокотравный (район Циркового озера), Cb-11 - кедрово-еловое редколесье (долина руч. Горный), $\mathrm{Cb}-12$ - кедрово-еловое редколесье (пойма руч. Тушканчик), $\mathrm{Cb}-13$ - кедрово-пихтово-еловый лес разнотравно-папоротниковый (долина р. Таловка, экотропа на г. Борус), Cb-14 - пихтово-кедрово-еловое редколесье (тропа на г. Тушканчик). Отроги Кузнецкого Алатау (Ширинский район, Хакасия): Cb-15 - смешанный лес разнотравно-осочковый (окр. п. Коммунар).

Все изученные популяции $C$. bracteata относятся к нормальному типу. Среди возрастных групп доминируют особи имматурного (17-42 \%) и виргинильного (23-47 \%) возрастных состояний. Максимальная плотность наблюдается в пойме высокогорного ручья (Cb-12) - 96 особей на 1 м², минимальная - в затененном пихтарнике $(\mathrm{Cb}-5)$ - 13 особей на 1 м². Преобладание генеративных особей отмечено только для популяции $\mathrm{Cb}-2$, произрастающей в пределах Красноярской лесостепи.

Максимальная внутрипопуляционная изменчивость и скоррелированность морфологических признаков характерна для красноярских популяций (Cb-1, Cb-2, Cb-3) и популяций, произрастающих в условиях высокогорий (Cb-9, Cb-10), а минимальная - для пойменного пихтарника (Cb-8).

Для оценки морфологического сходства изучаемых популяций использовался кластерный анализ. В обработке применялся метод Уорда. В качестве меры сходства использовалось Евклидово расстояние. В анализе использовались признаки, выявленные при проведении компонентного анализа и имеющие максимальные веса при главных компонентах. На дендрограмме сходства (рис. 1) отмечается разделение на 4 кластера: 1 - популяции, не имеющие клубня в пазухе прикорневого листа (Cb-13, $\mathrm{Cb}-15) ; 2$ - популяции с длинными осевыми частями и крупными вегетативными органами $(\mathrm{Cb}-3, \mathrm{Cb}-$ 6, $\mathrm{Cb}-8) ; 3$ - высокогорные западносаянские популяции, особи которых характеризуются небольшими размерами $(\mathrm{Cb}-9, \mathrm{Cb}-10, \mathrm{Cb}-11, \mathrm{Cb}-12) ; 4$ - популяции растений средних размеров $(\mathrm{Cb}-1, \mathrm{Cb}-2, \mathrm{Cb}-4$, $\mathrm{Cb}-5, \mathrm{Cb}-7, \mathrm{Cb}-14)$.

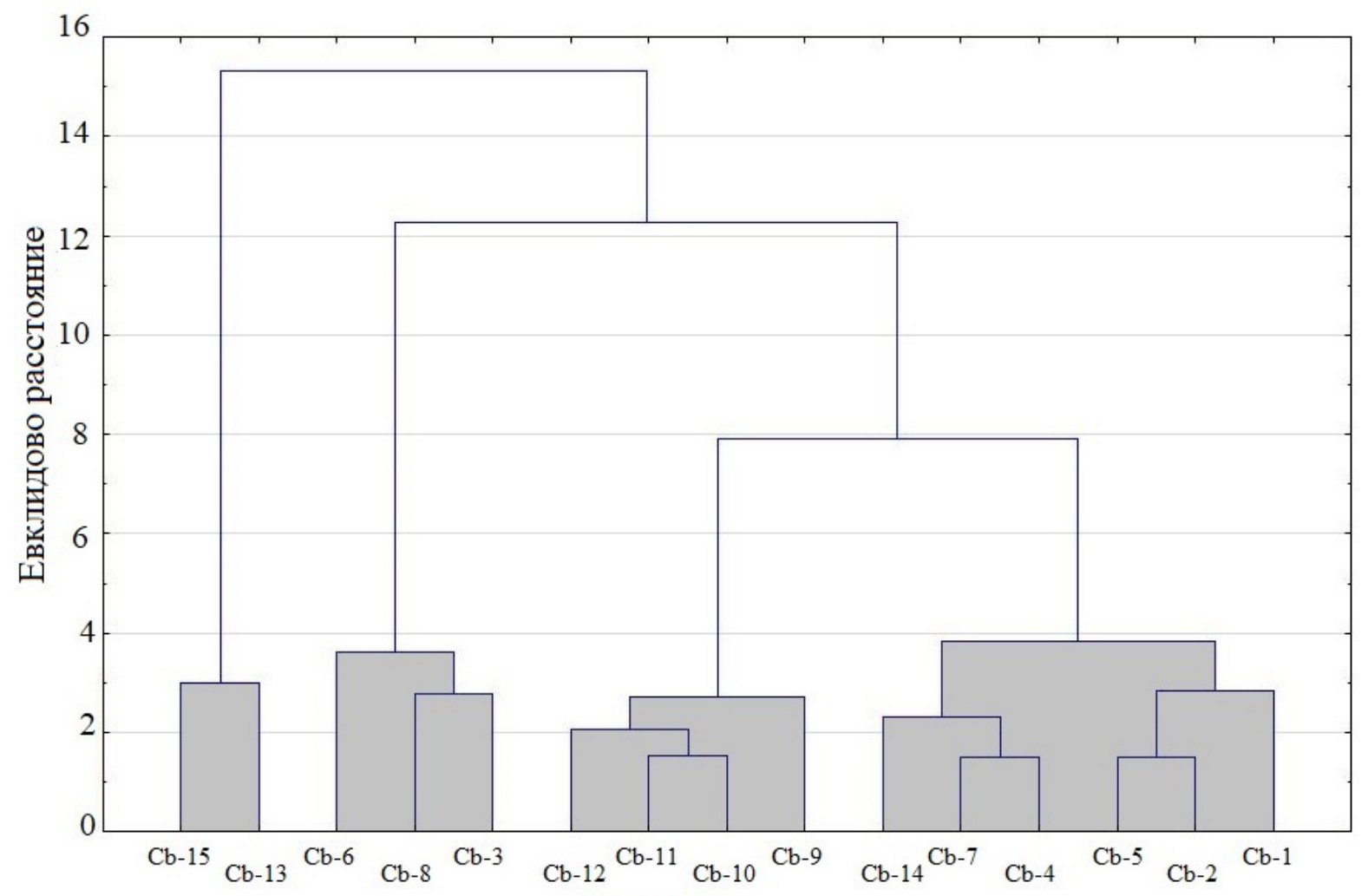

Популяции

Рис. 1. Дендрограмма сходства популяций Corydalis bracteata на основе морфометрических данных. 
Высокогорные западносаянские популяции характеризуются короткими осевыми органами, мелкими прицветниками и листьями, короткими цветоножками, редко встречающимися мелкими клубнями в пазухе прикорневого листа, близко расположенными цветками на цветоносе. Для популяций, произрастающих в отрогах Кузнецкого Алатау и на Борусе, отмечается отсутствие клубенька, длинные цветоносы с большим количеством цветков (до 21 шт.), сильно рассеченные прицветники с большим количеством зубчиков. Популяции, собранные во всех остальных местообитаниях, обладают средними значениями изучаемых показателей, и занимают промежуточное положение. Размеры плодов и венчиков растений всех популяций достоверно не различаются.

Генетический полиморфизм хохлатки изучен на примере популяций, произрастающих в пределах красноярской лесостепи (Cb-2, Cb-3), Восточного Саяна (Cb-4), Западного Саяна $(\mathrm{Cb}-6, \mathrm{Cb}-7, \mathrm{Cb}-$ 9, $\mathrm{Cb}-13)$ и Кузнецкого Алатау (Cb-15). В анализе использовались ISSR-праймеры, обладающие наибольшим полиморфизмом: 17898B (CA) 6 AC), 17899B (CA) 6 GG), HB9 (GT) $\left.{ }_{6} \mathrm{GG}\right), \mathrm{HB} 10$ (GA) $\left.\mathrm{CC}\right), \mathrm{HB} 12$ (CAC) $\left.)_{3} \mathrm{GC}\right), \mathrm{HB} 13$ (GAG) $\left.)_{3} \mathrm{GC}\right), \mathrm{HB} 14$ (CTC) ${ }_{3} \mathrm{GC}$ ) (Zietkiewicz,1994). В ходе анализа выявлено 162 фрагмента ДНК, процент полиморфизма которых суммарно составляет 99,38. Число амплифицированных фрагментов ДНК, в зависимости от праймера, варьировало от 11 (17898В и НВ9) до 49 (НВ12).

Максимальный уровень полиморфизма ДНК зафиксирован при использовании праймера НВ12 $(84,53 \%)$. Уровень генетического разнообразия в популяциях варьирует от 41,36 до 77,16 \% и имеет максимальные показатели в Cb-13 (г. Борус, $\mathrm{P}=77,16 \%$; $\mathrm{H}_{\mathrm{e}}=0,2696 ; \mathrm{I}_{\mathrm{o}}=0,4060$ ). Также высокие показатели генетической изменчивости отмечены для низкогорной западносаянской популяций $\mathrm{Cb}-6(\mathrm{P}=$ $\left.69,14 \% ; \mathrm{H}_{\mathrm{e}}=0,2299 ; \mathrm{I}_{\mathrm{o}}=0,3506\right)$. Минимальные значения генетического разнообразия зафиксированы для популяции $\mathrm{Cb}-4$, произрастающей в пойме р. Лалетина $\left(\mathrm{P}=41,36\right.$ \%; $\left.\mathrm{H}_{\mathrm{e}}=0,1368 ; \mathrm{I}_{\mathrm{o}}=0,2086\right)$.

Дендрограмма сходства, построенная на основе генетических данных (рис. 2), показывает достоверное объединение популяций, произрастающих в окрестностях г. Красноярска (Cb-2 и Cb-4) и популяций, не имеющих клубенька в пазухе прикорневого листа (Cb-13 и Cb-15). Популяция $\mathrm{Cb}-6$, характеризующаяся клубнем овальной формы, что является диагностическим признаком C. talpina, занимает обособленное положение. Таким образом, диагностическими признаками можно считать расположение листа на стебле, форму листовой пластинки, наличие и форму клубенька в пазухе прикорневого листа, форму и рассеченность прицветника.

Проведенный анализ установил, что возрастной спектр популяций относится к нормальному типу с преобладанием особей имматурного и виргинильного возрастных состояний. Группа растений Corydalis bracteata s. 1. является гетерогенной. При проведении кластерного анализа, на основании генетических данных, обнаружено, что наибольшим генетическим сходством обладают популяции, произрастающие в окр. г. Красноярск, которые морфометрически схожи с большой группой разнородных растений и характеризуются средними морфометрическими показателями и, предположительно, являются классической $C$. bracteata. Так же обособленной от всех группой являются генетически схожие популяции, произрастающие в С-Шушенском Бору и в окр. д. Коммунар, которые по морфометрическим данным создают отдельный кластер, не имеющих клубеньков в пазухе прикорневого листа. Обособленная западносаянская популяция, обладающая большими размерами вегетативных органов и несущая большой вытянутый клубенек в пазухе прикорневого листа, предположительно является C. talpina, описанной в 2015 г. Диагностическими признаками являются наличие и форма клубенька в пазухе прикорневого листа, форма и степень рассеченности прицветника.

Таким образом, проведенный анализ показал, что популяции желтоцветковой хохлатки на территории южной части Красноярского края и Хакасии характеризуются морфологическим и генетическим разнообразием. Наибольшим генетическим сходством обладают популяции, произрастающие в окр. г. Красноярска, которые морфологически сходны с большинством изученных популяций из Западного и Восточного Саян. Сходство данных популяций проявляется в наличии небольшого клубенька шаровидной формы в пазухе чешуевидного листа, что сближает данные популяции с видом $C$. bombylina, описанным Н. В. Степановым (2015). Отдельную генетически обособленную группу образуют популяции, произрастающие в Кузнецком Алатау и в пойме р. Таловка (г. Борус). Основное отличие данных популяций от остальных заключается в отсутствии дополнительного клубенька в пазухе чешуевидного листа. Согласно данным Н. В. Степанова (2015), данные популяции ближе к классическому 
виду C. bracteata. Генетически обособленная западносаянская популяция, обладающая большими размерами вегетативных органов и несущая дополнительный крупный клубенек вытянутой формы, предположительно является видом C. talpina. Диагностическими признаками, позволяющими разделить популяции хохлатки, являются наличие и форма клубенька в пазухе чешуевидного листа, форма и степень рассеченности прицветника.
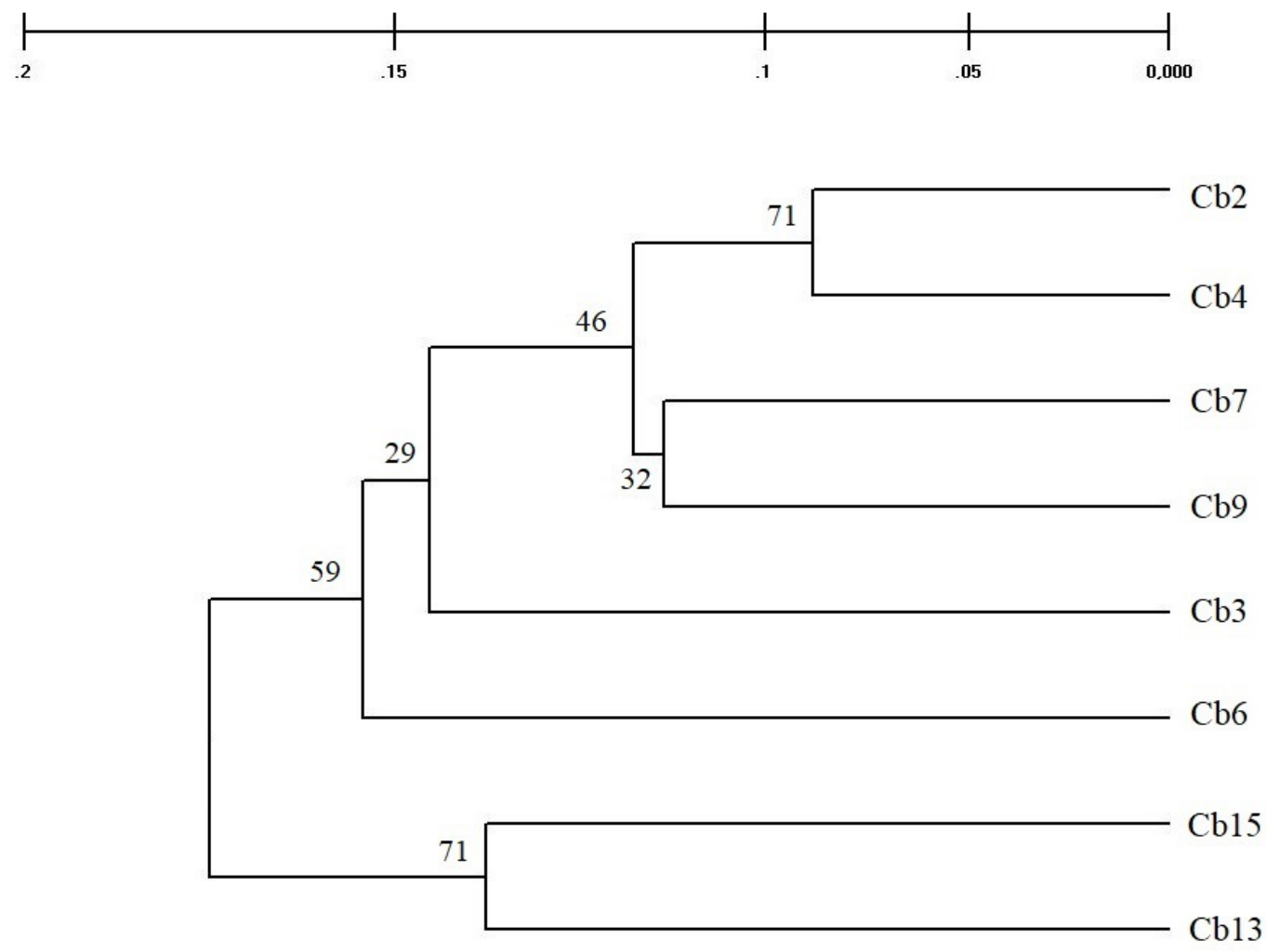

Рис. 2. Дендрограмма сходства популяций Corydalis bracteata на основе данных ISSR- анализа.

\section{ЛИТЕРАТУРА}

Михайлова М. А. Критический обзор хохлаток (Corydalis Vent., Fumariaceae) секции Archaeocapnos M. Рор. // Новости сист. высш. раст. - Л.: Наука, 1982. - Т. 19. - С. 98-104.

Пешкова Г. А. Семейство Fumariaceae DC. Дымянковые // Флора Сибири: Berberidaceae - Grossulariaceae. Новосибирск: Наука, 1994. - Т. 7. - С. 32-43.

Положий А. В., Лошкарева Л. Н., Гудошников С. В., Копанева Г. А. Семейство Fumariaceae DC. Дымянковые // Флора Красноярского края: Рараveraceae - Rosaceae. - Томск: Издательство Томского университета, 1964. - Вып. 5. - С. 7-8.

Cтепанов Н. В. Новые данные о желтоцветковых хохлатках (Corydalis DC. - Fumariaceae) секции Corydalis Красноярского края // Вестник КрасГАУ, 2015. - Вып. 6. - С. 175-182.

Zietkiewicz E., Rafalski A., Labuda D. Genome fingerprinting by simple sequence repeat (SSR)-anchored polymerase chain reaction amplification // Genomics. - Canada, 1994. - № 20 (2). - C. 176-183. 